\title{
ПРОБЛЕМА ЗАХИСТУ ТЕЛЕМЕДИЧНОЇ ІНФОРМАЦІЇ: НОРМАТИВНО- ПРАВОВІ ТА ОРГАНІЗАЦІЙНІ АСПЕКТИ З ДОСВІДУ РЕСПУБЛІКИ ПОЛЬЩА
}

\author{
${ }^{1}$ університет Бєльсько-Бялої, Республіка Польща \\ ДВНЗ «Тернопільський державний медичний університет \\ імені І. Я. Горбачевського МОЗ України»
}

В. П. Марценюк ${ }^{1}$, Н. Я. Климук, І. С. Гвоздецька

\begin{abstract}
В роботі вивчається проблема захисту телемедичної інформації. Проведено класифрікацію медичних даних з урахуванням діючих стандартів в аспекті захисту інформації в процесах як авторизації користувачів, так і безпеки опрацювання медичної інфрормації. Докладно вивчені питання захисту інформації в процесах як стаціонарного, так і амбулаторного лікування. Представлено чинну законодавчу базу щодо захисту телемедичної інформації Республіки Польща.
\end{abstract}

Ключові слова: телемедицина, захист медичної інорормації, нормативна база телемедицини, система охорони здоров'я Польщі.

\section{ПРОБЛЕМА ЗАЩИТЫ ТЕЛЕМЕДИЦИНСКОЙ ИНФОРМАЦИИ: НОРМАТИВНО-ПРАВОВЫЕ И ОРГАНИЗАЦИОННЫЕ АСПЕКТЫ ИЗ ОПЫТА РЕСПУБЛИКИ ПОЛЬША}

\author{
В. П. Марценюк ${ }^{1}$, Н. Я. Клымук, И. С. Гвоздецкая \\ ${ }^{1}$ Университет Бельско-Бялой, Республика Польша \\ ГВУЗ «Тернопольский государственный медицинский университет \\ имени И. Я. Горбачевского МЗ Украины»
}

\begin{abstract}
В работе изучается проблема защиты телемедицинской информации. Проведена классификация медицинских данных с учетом действующих стандартов в аспекте защиты информации в процессах, как авторизации пользователей, так и безопасности обработки медицинской информации. Детально изучены вопросы защиты информации в процессах как стационарного, так и амбулаторного лечения. Представлена действующая законодательная база относительно защиты телемедицинской инорормации Республики Польша
\end{abstract}

Ключевые слова: телемедицина, защита медицинской информации, нормативная база телемедицины, система здравоохранения Польши.

\section{ON PROBLEM OF TELEMEDICINE INFORMATION SECURITY: LEGISLATIVE AND ORGANIZATIONAL ASPECTS BASED ON EXPERIENCE OF REPUBLIC OF POLAND}

\author{
V. P. Martsenyuk ${ }^{1}$, N. Ya. Klymuk, I. S. Gvozdetska \\ ${ }^{1}$ University of Bielsko-Biala, the Republic of Poland \\ I. Ya. Horbachevsky Ternopil Medical State University of Ministry of Health of Ukraine
}

In the work the problem of telemedicine information security is studied. Classification of medical data from viewpoint of existing standards for information security in processes of both users authentification and security of processing medical information is fulfilled. Topics of information security in processes of both closed and open treatment are studied in details. There is presented existing legislative documents with respect to telemedicine information security of Republic of Poland.

Key words: telemedicine, protection of health information, telemedicine regulatory framework, the Polish health care system.

(c) В. П. Марценюк, Н. Я. Климук, І. С. Гвоздецька 
Вступ. Телемедицина - тобто медицина «на віддалі» - найновіша форма надання медичних послуг і профілактичного огляду, що поєднує в собі елементи телекомунікації, інформатики та медицини. Використання нових технологій уможливлює подолання географічних бар'єрів і обмін спеціалізованою інформацією. Пересилання зображень ЕКГ, УЗД та МРТ високої роздільної здатності уможливлює встановлення діагнозу на місці, дистанційно віддаленому від того, де обстежується пацієнт (це стосується переважно радіології, кардіології і дерматології). Телемедицина використовується також в хірургії під час оперативних втручань - $з$ метою так званої роботизації втручань.

Сучасна технологія, що використовує високопродуктивні процесори і алгоритми для цифрової обробки і компресії сигналів, уможливлює передавання зображень високої роздільної здатності, а також інтерактивну аудіовізуальну трансляцію 3 винятковою точністю в реальному часі. Відеокомунікаційні системи (відеокодери) працюють на загальнодоступних цифрових лініях ISDN, в Iнтернет, а також на супутникових передавальних лініях, що з’єднують абонентів з відповідними параметрами передачі пакетів медичних даних.

Приклади застосування телемедицини, що походять 3 прагнення «зменшення віддалі» між пацієнтом та лікарем (принцип «єдиності місця та часу обстеження») включають спеціалізовані консультації, обстеження, періодичні огляди, довготривале лікування, моніторинг пацієнтів і результатів лікування, асистування при складних хірургічних втручаннях, медицину надзвичайних станів, медичне рятівництво.

Конкретні переваги телемедицини включають перш за все:

- полегшення мешканцям малих міст і сіл доступу до спеціалізованого медичного обстеження;

- д допомогу в наданні спеціалізованих медичних послуг і консультацій для невеликих лікувальних закладів;

- покращення профілактичного огляду на ізольованих або віддалених територіях, швидкий діагноз і медичну допомогу в рятувальній службі;

• полегшений доступ до медичної допомоги при нещасних випадках або в процесі природньої катастрофи;

- обмеження госпіталізації і необхідних відвідувань пацієнтів;

- зменшення загальних коштів на лікування i профілактичний огляд в країні;
• покращення можливостей для підвищення рівня кваліфікації медперсоналу;

- економію за рахунок удосконалення адміністративних повноважень;

- полегшення проведення наукових досліджень, які до цього вимагали транспортування, а також об’єднання в єдине ціле даних, розпорошених по різних закладах охорони здоров'я;

- зменшення комунікаційних бар’єрів між закладами охорони здоров'я.

Теоретичні основи для функціонування телемедичних систем в Україні були закладені в роботах О. П. Мінцера [4], О. С. Коваленка [1], О. Ю. Майорова [3], Л. С. Годлевського [5], Ю. Є. Ляха [2], В. П. Марценюка [20, 21], I. І. Хаімзона [7].

Наукові дослідження щодо впровадження телемедицини в Польщі проводяться під егідою Польського товариства телемедицини [28] в Інституті біокібернетики і медичної біоінженерії Польської академії наук [24], Інституті медичної технології і апаратури [12], на факультеті інформатики Шльонського університету, Гірничо-металургійній академії (м. Краків) [10, 11], у Вроцлавському політехнічному та Жешувському університетах [9].

Можливості, які пропонує сучасна технологія для передачі медичної інформації в телемедицині, заставляють ретельніше підійти до питань, пов'язаних із захистом даних: як з авторизацією користувачів, так і медичної інформації, що отримується, обробляється, передається, зберігається в процесі телемедичних сеансів. На жаль, існуюча вітчизняна нормативно-регулююча правова база не відображає повною мірою аспекти захисту медичної інформації в телемедицині.

Питання захисту інформації в комп’ютерних системах та мережах представлені в працях вітчизняних вчених О. К. Юдіна, О. Г. Корченка [8], М. П. Карпінського [6].

При розробці вітчизняних регламентуючих документів щодо захисту телемедичної інформації варто скористатися успішним досвідом застосування телемедицини у країн-сусідів, передусім Польщі. Тому метою роботи $€$ вивчення нормативно-правових аспектів щодо вирішення питань захисту телемедичної інформації як у випадку стаціонарного, так і амбулаторного лікування на прикладі галузі е-здоров’я Республіки Польща.

Класифікація і стандартизація медичної інформації в галузі е-здоров'я. Медична інформація є основою комунікації в галузі е-здоров’я (e-health). Йдеться про комунікацію лікарів, фармацевтів, 
медичних сестер і лаборантів з пацієнтами, а також про системну комунікацію, тобто обмін текстовими (діагнози, описи стану/хвороби, дані пацієнта тощо) або графічними (зображення КТ і МРТ, графіки ЕКГ і ЕЕГ тощо) даними у рамках пристроїв/систем медичної інформатики. Відповідно спеціалізовані словникові засоби, тобто обрана i загально прийнята сфера і формат застосовуваного словникового запасу, творять простір понять, на який опирається такий обмін інформації (локальний i/або системний) в даній галузі телемедицини.

В медицині та сфері охороні здоров'я словниковий запас походить 3 медицини, фармації, епідеміології та інших споріднених галузей, отже $\epsilon$ зрозумілим лише для певної групи людей. До того ж трапляється, що особи, які походять з різних середовищ чи медучних шкіл, послуговуються різними термінами для визначення тих самих явищ або визначають тим самим терміном інші явища. 3 метою уникнення виникаючих 3 цього непорозумінь і неузгодженості почато творення і каталогізація словникового запасу, приписуючи окремим термінам визначене базове однозначне значення. Таким чином, виникли словники термінів, що характеризуються визначеною логікою i структурою, а також класифікатори. В разі медичного обстеження на практиці використовуються, зокрема, класифікації, що стосуються:

- хвороб і медичних проблем;

- процедур, включаючи хірургічні, діагностичні та інші;

- лікувальних засобів і медичних матеріалів, включаючи медичне обладнання;

- лікувальних закладів;

- медичних професій і спеціальностей.

Класифікації і системи кодування є основною складовою частиною медичної інформатики, що розвивається протягом останніх п'ятнадцати років. $€$ елементами метасистеми е-здоров'я, для якої норми і стандарти визначені через приписи стандартизаційних міжнародних (ISO), регіональних (CEN) і державних (ANSI, AFNOR, BSI, DIN, PKN та ін.) організацій. Грунтуючись на медичних знаннях, вони охоплюють не тільки системи понять, але також прийняті, умовні форми документації щодо хвороб/пацієнтів разом $з$ додатками, що обслуговують цю документацію.

Стандартизація охоплює також (на прикладі США [14]) класифікацію хвороб і медичних проблем (ICD-10), хірургічних і інших процедур (ICD9-CM, OPS-301), а також безпосередньо хворих/ пацієнтів (DRG). Увінчуванням цієї піраміди стандартів є система Unified Medical Language System (UMLS) - метатезаурус, що поєднує багато різних систем кодування і класифікації та функціонує під егідою National Library of Medicine.

Існує багато осередків, які розробили і розповсюдили системи кодованих словників для різних цілей в сфері охорони здоров'я. Характеризуючи системи кодування в сфері охорони здоров'я, слід зазначити рису, пов'язану з територіальною ознакою їх дії.

Місцеві системи і класифікації (квазістандарти) створені з думкою про конкретного одержувача інформації в даній країні. Дуже часто вони є знаряддям, що служить для виконання фінансових розрахунків, i (як таке) виникло з потреб платників медичних послуг, наприклад:

- Current Procedural Terminology [25] - класифікація медичних процедур, що створена в American Medical Association, має на меті надання інформації щодо послуг, наданих для пацієнта; одержувачами цієї інформації $є$ в головному платники медичних послуг, наприклад, фірми і фонди медичного страхування;

- International Classification of Diseases - 9th Revision - Clinical Modification - Procedures [14] - класифікація, розроблена в США (незважаючи на назву «міжнародна»), за дорученням Health Care Financing Administration, з метою розрахунку хірургічних процедур в США;

- Read Codes - система, створена в Center for Coding and Classification на потреби National Health Service у Великобританії;

- Internationale Klassifikation der Prozeduren in der Medizin [16] - німецька класифікація процедур, що служить для розрахунків для медичних страхових кас.

Міжнародні системи і класифікації створюються міжнародними організаціями, які часто $€$ пов'язаними зі Всесвітньою організацією охорони здоров’я, i їх головним завданням є уніфікація термінології, що відноситься до процесів світового масштабу. Приклади таких класифікацій :

- ICD-9, ICD-10 - International Classification of Diseases and Health Related Problems [14, 15] основна класифікація, що є стандартом назв і кодування хвороб, видана Всесвітньою організацією охорони здоров'я (WHO);

- International Classification for Primary Care [13] розроблена Всесвітньою організацією сімейних лікарів (WONCA) - уможливлює опис явищ 


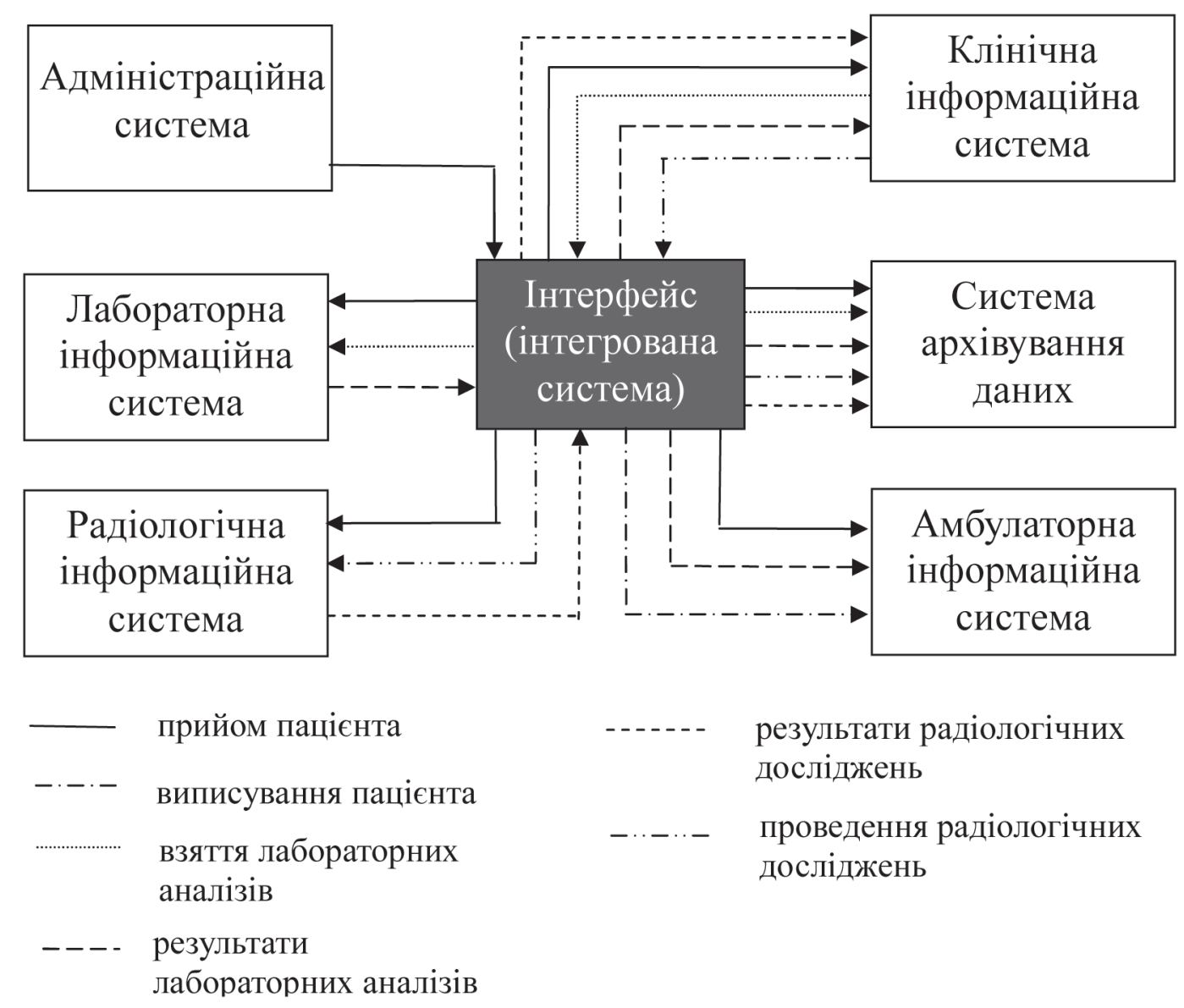

Рис. 1. Модель передачі медичної інформації згідно стандарту UN/EDIFACT (ISO 9735:1987)

3 метою визначення стану здоров’я популяції і медичних потреб, а також оцінки якості медичних послуг на первинному рівні;

- International Classification for Health Accounts розроблена під патронатом Організації економічної співпраці і розвитку (ОЕСР), в співробітництві з WHO i Eurostat 3 метою класифікації видатків на охорону здоров’я.

Багато із систем, створених локально в межах країн на потреби конкретних одержувачів, з плином часу стали міжнародними і $є$ тепер неформальним світовим стандартом. Прикладом може бути ECRI (Номенклатура медичних пристроїв) або ж набуваючий усе більше користувачів ICD9-CM-Procedures.

Зауважимо, що описані вище системи кодування не гарантують безпеки медичної інформації, а лише уніфікують ії розуміння і використання.

Охорона медичних даних пацієнта при стаціонарному лікуванні. На сьогодні медична інформатика у рамках стаціонарного лікування посилається на два прийняті стандарти:
- HL7 v.3.0 - як стандарт обміну текстових повідомлень (ISO/HL7 21731:2006), що співпрацює із стандартом UN/EDIFACT (ISO 9735:1987);

- DICOM - як стандарт обміну для медичних зображень.

Для адміністраторів, що управляють інформаційною інфраструктурою в стаціонарі (клініка, лікарня, санаторій тощо) важливим завданням $є$ створення політики безпеки, тобто формування цілісного, детального й узгодженого 3 діючим законодавством набору положень, правил і процедур, згідно з якими будуть побудовані, відкриті для доступу і керування ресурси проекту е-здоров'я.

Політика безпеки повинна також бути сумісною з нормами, що охоплюють такі питання:

- безпека передачі персональних даних в системі охорони здоров'я;

- безпечне пересилання електронного медичного запису в IT-мережах;

- безпечна ідентифікація користувача даних у системі охорони здоров'я; 
- безпека і засвідчення всіх доступних даних щодо стану здоров’я.

Лише знайомство з нормами і стандартами, що стосуються медичної інформатики, не гарантує розробки надійної політики безпеки (що забезпечує відповідний рівень безпеки). Але без знайомства з ними неможливе впровадження відповідної політики охорони медичних інформаційних систем i даних, що в них обробляються.

Забезпечення захисту медичних даних на основі стандарту HL7. Health Level Seven International (HL7) - організація, яка виникла в 1987 році в США (Мічіган) та займається розвитком взаємодії в сфері обміну медичною інформацією. Організація $є$ акредитованою ANSI, що дає їй повне право на встановлення стандартів. Сферою дії HL 7 є обробка клінічних та адміністративних даних.

Згідно із статутом організації її метою є «гарантування стандартів обміну і інтеграції даних, які підтримують клінічну опіку над пацієнтом, а також управління медичними послугами, їх постачання i користування ними. Зокрема тут йдеться про створення гнучких і економних підходів до різних стандартів, рекомендацій, методик, а також пов'язаних з ними супутніх послуг, пов'язаних 3 різноманітними інформаційними системами, використовуваними в сфері охороні здоров’я».

HL7 v.1.0 був схвалений ANSI як стандарт 26 липня 1999 року. На сьогодні стандартом $\epsilon$ версія 3.0, схвалена через ANSI в 2005 році i також прийнята як міжнародна норма ISO/HL7 21731:2006 [18]. Від квітня 2013 року специфікація цього стандарту доступна безкоштовно за адресою www.hl7.org (включаючи 15 розділів і 4 додатки). Визначаючи лише модель/основний модуль створення повідомлення, версія 3.0 уможливлює запис повідомлень в різних популярних форматах, таких як наприклад, XML чи популярні для медицини EDIFACT i ER7.

Так, в Польщі розроблено формати документів згідно з нормою UN/EDIFACT (ISO 9735:1987) 3 метою їх електронного обміну (EDI [17]) між закладами охорони здоров'я (лікарнею) і Національним фондом здоров’я (NFZ) (Листок лікарняного лікування - ZDR100 і ZDR200).

HL7 3.0 впроваджує ряд моделей сутностей i активностей, що зустрічаються в службі охорони здоров’я, і на цій підставі відображає їх у вигляді записуваного повідомлення. Основною розробленою в HL7 моделлю є об’єктна модель інформації в службі охорони здоров’я, що означується як ре- ференційна, під назвою RIM (Reference Information Модель). Така модель через застосування мови об’єктного моделювання UML (Unified Modeling Language) містить 123 класи об’єктів, можливі стани та реляції між об’єктами. Спрощенням такої моделі є інформаційна модель повідомлення МIM (Message Information Model), що використовує лише ті класи, на які відображаються об’єкти.

Поряд з розробкою нового стандарту повідомлення, референційної моделі та типів документів XML для повідомлення, організація HL7 вирішила розробити архітектуру електронних медичних записів пацієнта. Грунтуючись на референційній моделі RIM, розроблено ряд форм документів DTD та процедури обміну. Такий модуль отримав назву PRA - Patient Record Architecture. Документи PRA реалізовані на XML, отже не залежать від апаратури або аппаратно-програмних рішень. Вони уможливлюють передачу повідомлення щодо пацієнта між різними лікувальними закладами також з використанням норми EDIFACT, інтегрованої з HL7.

Конструкція повідомлення створюється на підставі норми ISO 9735 (EDI), що описує правила синтаксису. Підсумовуючи, можна сказати, що застосування норми EDIFACT є легким, проте документація її опису (понад 2700 сторін) становить серйозну перешкоду.

Обмеження норми EDIFACT, з огляду на універсальність її застосування, унеможливлюють передачу різних медичних даних, наприклад, зображень чи сигналів. Тому норма EDIFACT прийнята в медицині як норма, що використовується з метою підготовки звітів і адміністрування (наприклад, в реляції «постачальник медичних послуг» - «страховик або Національний фонд здоров’я (NFZ)»).

Слід звернути увагу на той факт, що файли HL7 та EDIFACT містять комплект текстових даних про пацієнта. Тому польське законодавство має усі підстави вимагати виконання умов охорони даних, що пов'язані не лише з безпечною ідентифікацією користувача цієї інформації (PN-EN 12251:2005Р - Медична інформатика - Безпечна ідентифікація користувача в системі охорони здоров’я - Управління і безпека авторизації з використанням паролів) [26], але і з охороною самої інформації (PN-ISO/IEC 17799:2007 - Інформаційна технологія - Технології захисту інформації - Практичні принципи управління захистом інформації; PN-ISO/IEC 27001:2007 - Інформаційна технологія - Технології захисту інформації - Системи управління захистом інформації - Вимоги; 
PN-EN ISI 27799:2010 - Інформатика в системі охорони здоров’я - Управління захистом інформації в системі охорони здоров’ я з використанням ISO/IEC 27002).

Забезпечення захисту медичних даних на основі стандарту DICOM. У медичних інформаційних системах, крім текстових даних, часто потрібно пересилати графічні дані, такі як рентгенівські зображення чи записи УЗД-досліджень. 3 цією метою розроблено стандарт DICOM. Розробником стандарту є ACR/NEMA (American College of Radiology/ National Electrical Manufacturers Association). Перша версія стандарту була опублікована в 1993 році. Нині чинна версія стандарту була прийнята в 2004 році.

Стандарт DICOM визначає інформаційні об’єкти, а також набори доступних послуг (сервісні функції) для даних інформаційних об’ єктів. Визначений ряд сервісів/функцій, які виконують ролі надавача і користувача сервісу в даному класі об’єктів. Нові об’єкти впроваджуються поступово, в міру появи на медичному ринку нових діагностичних пристроїв. Такі об’єкти приписуються до таких класів, як CT (комп’ютерна томографія), MRI (ядерний магнітний резонанс) або CR (комп’ютерна радіологія). Найважливішою перевагою стандарту DICOM є інтеграція візуальних даних з медичними даними в єдиному файлі. Тому суттєвим є формування файлу/пакету DICOM.

Окремий файл стандарту DICOM містить в собі як заголовок (у якому записані дані пацієнта, тип зображення, його розміри тощо), так і саме зображення, яке може включати інформацію в трьох вимірах. Зображення, що зберігається у файлі, може бути скомпресоване із застосуванням компресії із втратами (JPEG) та без втрат (TIFF).

Слід звернути увагу на той факт, що файл DICOM містить набір текстових і графічних даних щодо пацієнта. Тому польські закони накладають виконання умов щодо охорони цих даних, які пов'язані з безпечною ідентифікацією користувача цієї інформації (PN-EN 12251:2005P - Медична інформатика - Безпечна ідентифікація користувача в системі охорони здоров’ я - Управління і безпека авторизації з використанням паролів) [26], а також охороною безпосередньо цієї інформації (PN-ISO/IEC 17799:2007 - Інформаційна технологія - Технології захисту інформації - Практичні принципи управління захистом інформації; PN-ISO/IEC 27001:2007 Інформаційна технологія - Технології захисту інформації - Системи управління захистом інфор- мації - Вимоги; PN-EN ISI 27799:2010 - Інформатика в системі охорони здоров'я - управління захистом інформації в системі охорони здоров'я з використанням ISO/IEC 27002).

Представлені вище питання, пов’язані з системами стаціонарного лікування, не охоплюють усю проблематику захисту медичних даних. Тут звертають увагу [10] найперше на те, що в польській реальності системні інформаційні рішення медичних проблем часто трактуються швидше як вимоги $€ \mathrm{C}$, ніж для задоволення зрозумілих i очевидних потреб пересічного громадянина, пов'язаних з охороною його даних.

Захист медичних даних пацієнта в амбулаторному лікуванні. Під поняттям амбулаторного лікування (в польській медичній терміногогії вживається буквально термін «відкрите лікування» на відміну від «закритого» стаціонарного лікування) в системі охорони здоров’ я Польщі мають на увазі систему надання різноманітних медичних послуг для потребуючого громадянина - пацієнта. Слід звернути увагу, що згідно з укладеними Польщею угодами, пацієнтами польських закладів амбулаторного типу все частіше бувають громадяни інших держав Євросоюзу. Зазначається [10], що охорона медичних даних пацієнта при амбулаторному лікуванні в Польщі становить проблему через легкість отримання доступу до таких даних, як в результаті недостатнього нагляду, так і часто легковажності в поведінці медперсоналу по відношенню до пацієнта та інформації про нього, яка зберігається в існуючій медичній інформаційній системі.

Системні повідомлення є, з технічної точки зору, XML/XSD-файлами (у випадку текстових даних) або файлами DICOM (у випадку діагностики на основі зображень). 3 огляду на пересилання між системами (між надавачем послуг і призначеним суб’ єктом) вони повинні бути підписані за допомогою захищеного електронного підпису в розумінні Закону про електронний підпис (стаття 3, пункт 2) або підпису, підтвердженого довіреним профілем еPUAP в розумінні Закону про інформатизацію діяльності суб’єктів, які виконують публічні завдання (стаття 3, пункт 15).

Слід зауважити, що поняття медичної інформаційної системи, яке було визначене законом від 28 квітня 2011 року, було уточнене наказом міністра охорони здоров' я Польщі від 28 березня 2013 року з впровадженням таких обов'язкових норм:

- PN-EN ISO 13606-1:2013 - Інформатика в системі охорони здоров'я - Пересилання медичної 
електронної документації- Частина 1: Рекомендована модель;

- PN-EN ISO 13606-4:2009 - Інформатика в системі охорони здоров'я - Пересилання медичної електронної документації - Частина 4: Безпека;

- PN-EN ISO 13606-5:2010 - Інформатика в системі охорони здоров'я - Пересилання медичної електронної документації - Частина 5: Специфікація інтерфейсу;

- PN-ENV 13608-1:2003 - Інформатика в системі охорони здоров'я - Безпека пересилання даних в медичному догляді - Частина 1: Поняття i термінологія;

- PN-ENV 13608-2:2003 - Інформатика в системі охорони здоров'я - Безпека пересилання даних при медичному догляді - Частина 2: Безпечні об'єкти даних;

- PN-ENV 13608-3:2003 - Інформатика в системі охорони здоров'я - Безпека пересилання даних при медичному догляді - Частина 3: Безпечні канали пересилання даних;

- PN-EN 14484:2005 - Медична інформатика Міжнародний переказ медичних персональних даних, визначених директивою Євросоюзу щодо охорони даних - Високий рівень політики безпеки [27];

- PN-EN 14485:2005 - Медична інформатика Інструкції для оперування медичними персональними даними в міжнародних додатках з урахуванням директиви Євросоюзу щодо охорони даних.

Кілька із згаданих норм є обов'язковими до виконання відповідно до наказу Міністра охорони здоров'я від 6 червня 2013 р. щодо системи обліку ресурсів системи охорони здоров'я.

Моніторинг даних і медичний нагляд за пацієнтом вдома. Питання моніторигу з використанням телемедицини потрібно розглядати в просторі е-здоров'я і е-медицини в трохи ширшому аспекті, 3 урахуванням активних дій безпосередньо самого пацієнта, при трактуванні як істотних не лише елементів нагляду у рамках медичного теледогляду, але активного спонукання і нагляду пацієнта у рамках телереабілітації.

В обох випадках використовується рішення з області медичної інформатики і телемедицини. Пацієнт при цьому отримує швидкий доступ до консультації лікаря, а також точнішу діагностику стану свого здоров'я.

Телемедичний моніторинг як форма теледогляду. Пересічний громадянин сьогодні все ще має невеликі знання щодо форм і методів використання медичної телеінформатики в забезпеченні поточного моніторингу і догляду за станом організму. Можна зустрітися тут з елементами телемедичного догляду: негайного (наприклад, дослідження пульсу пульсоксиметром), вибіркового (наприклад, добове спостереження за обраними параметрами - Holter 24/48) або неперервного (наприклад, постійний кардіологічний нагляд стану пацієнта).

Як приклад теледогляду можна навести польське рішення телемедичного моніторингу - телемедичну інтернет-мережу MONTE [19]. Проект був розроблений на курсі медичної фізики фізичного факультету Університету імені Адама Міцкевича в Познані колективом під керівництвом професора Р. Кшимінєвскєго і зараз впроваджується в ряді регіонів Польщі.

Через телемедичну мережу MONTE пацієнт має можливість:

- отримання розширеного аналізу пульсової хвилі (пульсу) пульсоксиметром

- обстеження серця методом NURSE-ECG, тобто високороздільною електрокардіографією;

- online-консультації з лікарем.

Пульсоксиметр як телемедичний датчик. Пульсоксиметр є електронним пристроєм для неінвазивного вимірювання пульсу і насиченості крові киснем. Завдяки спеціальній комп'ютерній програмі PULS-HSR, розробленій в Університеті імені Адама Міцкевіча в Познані, виконується розширений аналіз пульсової хвилі. Програма надає інформацію про пульс, насичення киснем крові, про стан серцево-судинної системи моніторованого пацієнта, що є дуже корисним в ранній діагностиці хвороб серцево-судинної системи.

Аналіз пульсової хвилі PULS-HSR допомагає вчасно передбачити загрози такої патології, як аритмія серця, зміни міокарда, хвороби органів дихання, вади серцево-судинної системи; а також дозволяє контролювати вплив реабілітації, яка проводиться, та ліків, які приймаються, на стан кровообігу.

Слід зауважити, що аналіз пульсової хвилі рекомендований Європейським товариством артеріальної гіпертензії (EHS), як метод поточного контролю при активній реабілітації.

Телемедичне дослідження серия. При телемедичному дослідженні серця методом NURSE-EEG, тобто при використанні електрокардіографії високої роздільності, отримані результати легші для аналізу і краще, ніж типовий графік електрокардіограми, 
сприймаються при демонстрації самим пацієнтом, що може служити інструментом для заохочення і основою для реабілітації.

Реабілітація та телереабілітація. Згідно із Законом Польщі про професійну і суспільну реабілітацію (стаття 7, пункт 1) «... реабілітація неповноцінних осіб означає комплекс дій, зокрема організаційних, лікувальних, психологічних, технічних, підготовчих, освітніх і суспільних, спрямованих на досягнення, при активній участі цих осіб, якомога найвищого їх рівня функціонування, якості життя і суспільної інтеграції» [29].

Таким чином, телереабілітація позначає сукупність цих дій, що реалізуються за допомогою телекомунікаційної інфраструктури на віддалі.

У публікаціях на тему телереабілітації можна знайти однак різноманітні визначення цього поняття:

- «телереабілітація - це сукупність технологічної інфраструктури, створеної з метою збільшення доступу до реабілітаційного догляду і подовження часу його надання для неповноцінних осіб, особливо тривало хворих» [22];

- «телереабілітація - це сукупність реабілітаційних (консультації, діагностика, терапія) послуг, що надаються за посередництвом інтерактивних телекомунікаційних технологій» [23].

Як випливає з вищенаведених означень, телереабілітація входить в сферу описуваного вище поняття телемедицини.

Причини появи і розвитку цієї галузі ховаються в процесах, що відбуваються в технологічній та медичній сферах. У технологічній сфері безперечно одним з них є динамічний прогрес телекомунікаційної інфраструктури, який відбувається протягом останнього десятиріччя. Постійне збільшення можливостей, швидкості й ефективності передачі інформації на великі відстані - з одночасним спадом цін на ці послуги й інфраструктури - приводить до постійного зростання віддалі, яку можна охопити телереабілітаційними послугами.

Дослідження на тему дієвості реабілітації доводять також, що для того, щоб реабілітаційний процес приніс задуманий ефект, повинні бути дотримані три умови:

- 1 Процес реабілітації повинен початися якнайшвидше з моменту появи причини неповноцінності.

- 2. Процес реабілітації для даного пацієнта повинен бути настільки інтенсивним, наскільки це тільки можливо відносно оцінки його стану.
- 3. Процес реабілітації повинен тривати аж до отримання можливих для повернення функцій. Третя умова у більшості випадків - особливо для хронічних хвороб - вказує на необхідність продовження процесу реабілітації вдома. Таким чином, телереабілітація веде до появи нових парадигм у медичній реабілітації та зростання технологічних можливостей, які допомагають діяти згідно з цими парадигмами.

Як випливає зі змісту доступних публікацій на тему телереабілітації, найчастіше застосовується вона для таких питань:

- дистанційна функціональна оцінка пацієнтів;

- управління доглядом пацієнта;

- дистанційна реалізація реабілітаційних програм;

- телеконсультації і парамедична освіта пацієнта.

На сьогодні провідним інструментом, за посередництва якого можливим є застосування телереабілітації, є Інтернет.

Питання групування медичних даних. Медичні дані пацієнта на практиці генеруються в різних, інколи доволі віддалених місцях (кабінет лікаря, операційна, лабораторія, рентгенкабінет тощо) i хоча теоретично зберігаються в історії хвороби, та на практиці існують довго і по-різному в місцях своєї появи. Особливо стосується це цілої групи діагностичних пристроїв, обладнаних автономними ресурсами пам’яті.

Наскільки можна керувати такою розпорошеною інформацією? Відповідь не є простою. Впроваджувана сьогодні медична інфораційна система спрямована на нормалізацію усіх інформаційних процесів, але проблемами залишаються старі звички і небажання до змін.

Прикладом позитивних змін є телемедицина в рятувальній медичній службі. Її застосування грунтується на телеінформатичній системі зв'язку, що забезпечує пересилання діагностичних даних, а також допомогу в надзвичайних ситуаціях, екстренних випадках, в результаті нещасних випадків. До світових лідерів (тобто до європейських країн $з$ найрозвинутішими системами екстренної телемедицини) належать Великобританія, Швеція, Норвегія, Фінляндія і Данія.

У польських лікарнях, починаючи від 2004 року, впроваджуються системи, які служать для передшпитальної діагностики гострої серцевої недостатності. Завдяки цьому принципово скорочується час від обстеження пацієнта до надання інвазійного лікування (зникає необхідність виконання додат- 
кових обстежень у районній лікарні). Системи екстренної телемедицини складаються 3 двох компонентів. Першим з них є спеціально пристосований для телетрансляції монітор-дефібрилятор, який знаходиться в реанімобілі або у шпитальному реанімаційному відділенні (Szpitalny Oddział Ratunk, SOR). Другий - це так звана медична приймальна станція (Medyczna Stacja Odbiorcza, MSO) - комп’ютер, який знаходиться в лікарняному кабінеті гемодинаміки, з інстальованим програмним забезпеченням, що забузпечує приймання даних з високою роздільністю та їх архівування. Станом на першу половину 2013 року в Польщі в цілодобовому режимі працювало 45 таких MSO.

Схема використання сучасної інформаційної технології є завжди така сама. Результати дослідження 12-канальної електрокардіографії, виконаної бригадою невідкладної допомоги, пересилаються за допомогою вбудованого в дефібрилятор модему до лікарні, в якій знаходиться MSO. Кардіолог, який здійснює цілодобове чергування в кабінеті гемодинаміки, аналізує отримані записи i, консультуючись з бригадою невідкладної допомоги по телефону, намічає подальший маршрут пацієнта. Консультація чергового кардіолога полягає не тільки в можливому направленні хворого на негайне інвазивне лікування (процедуру ангіопластики), але також включає рекомендації, що стосуються надання (вже в кареті швидкої допомоги) відповідних ліків. Водночас відділення інвазивної кардіології може під час транспортування хворого підготувати відповідне устаткування в операційному залі, що ще більше скорочує час до розкупорки судини, закупорка якої спричинила інфаркт.

Зібрана інформація залишається в пам'яті спеціально пристосованого для телетрансляції монітора-дефібрилятора (короткотерміново - до наступного запису), в комп'ютері MSO (це довготривала пам'ять 3 резервною копією) і становить початковий запис процесу лікування (дані переписуються з MSO/SOR до буферу пам'яті комп’ютера у відділенні подальшого перебування пацієнта).

Слід звернути увагу, що пацієнт в цілому не усвідомлює, що відбувається з його даними, а також якими шляхами вони передаються в процесі його порятунку або екстренного лікування.

Локальні реляційні бази даних (амбулаторія/ лікарня/клініка). Функціонування в Польщі медичних баз даних в амбулаторіях, лікарнях і клініках супроводжується критичними відгуками щодо забезпечення захисту інформації, особливо у випадку клінік і університетських клінічних лікарень, де «...розпорядником паперової документації є заклопотаний професор» [11].

Формальне впровадження медичних інформаційних систем, якому не передує аналіз загроз і оцінка ризику для збережених даних, без розробленої системної стратегії поведінки (політика безпеки інформації, впровадження, підтримка і постійне вдосконалення систем управління базами даних) спричиняє, що не можна розраховувати на реальні ефекти в дотриманні високого рівня охорони і безпеки медичних даних.

Спеціалізовані бази даних - експертні середовища (global e-health). У Польщі ініціативи, пов'язані 3 розповсюдженням телемедицини, концентруються в основному на розробці і впровадженні систем для передачі ЕКГ-сигналів через телефон (а також через мобільні телефони), ефективному пересиланні рентгенівських зображень, зображень УЗД, KT, MPT та ін. (DICOM) через Intranet або Internet з метою консультації, а також на надійній організації баз даних і необхідних систем контролю доступу до тих же банків інформації.

32001 року працює секція телемедицини Польського лікарського товариства, яка поставила за мету впровадження і розвиток ідеї телемедицини в Польщі. У секцію входять відомі професори, директори лікарень і клінік, лікарі різних спеціальностей. На жаль, на даний момент ще не створено власних експертних баз з можливістю регіонального використання (хоч є вже ряд досягнень і напрацювань в кардіології і хірургії). Тому секція зосереджується на співробітництві і використанні знань, відкритих для доступу у рамках міжнародних контактів.

Висновки. Бурхливий розвиток інформаційнокомп’ютерних технологій вражає щораз більшими можливостями системних рішень. Водночас щораз більше проявляється інформаційна неграмотність значної старшої частини суспільства, що у поєднанні з кризою, яка триває, та постійним браком ліній високої перепускної здатності поглиблює явище суспільного ізолювання значної частин громадян від доступу до е-спільноти та використання його благ.

Одночасно з'являються нові вимоги - які виходять 3 участі Польщі в ЄС і ОЕСР, з функціонування в спільній Європі (у EOG/EЕA і шенгенській зоні) пов'язані до того ж з потребами (включаючи інформаційно-медичні) громадян ЄС, що приїжджають до Польщі.

Зазначається [11], що існують проблеми, пов'язані з використанням виділених Польщі через 
EC ресурсів, призначених на розвиток і забезпечення системної безпеки (включаючи забезпечення телеінформатичної інфраструктури країни), не кажучи про безпеку даних в e-health. Введені в 2010 році зміни в галузі охорони інформації і пов’язані 3 ними дії Урядового центру безпеки Польщі щодо підвищення енергетичної безпеки країни становлять два важелі, які підтримують розпочату в 2013 році інтенсивну діяльність в сфері розвитку інформаційних систем, включаючи медичні інформаційні системи.

Великою проблемою залишається низький рівень знань старшої частини суспільства щодо потреб і можливостей сучасних рішень на основі інформаційно-комунікаційних технологій (включаючи телемедицину), а також брак доступу до мереж з високою перепускною здатністю для приватних користувачів

Також окремим питанням залишається експлуатація діагностичних систем з погляду медичної інженерії.

\section{Додаток.}

Правова база забезпечення охорони телемедичних даних в системі охорони здоров'я Польщі: 1. PN-EN 14485:2005 - Informatyka medyczna Wskazania dla operowania medycznymi danymi osobowymi w międzynarodowych aplikacjach z uwzględnieniem dyrektywy UE dotyczącej ochrony danych.

2. PN-EN ISO 13606-1:2013 - Informatyka w ochronie zdrowia - Przesyłanie elektronicznej dokumentacji zdrowotnej - Część 1: Model referencyjny.

3. PN-EN ISO 13606-4:2009 - Informatyka w ochronie zdrowia - Przesyłanie elektronicznej dokumentacji zdrowotnej - Część 4: Bezpieczeństwo.

4. PN-EN ISO 13606-5:2010 - Informatyka w ochronie zdrowia - Przesyłanie elektronicznej dokumentacji zdrowotnej - Część 5: Specyfikacja interfejsu.

5. PN-EN ISO/IEC 27799:2010 - Informatyka w ochronie zdrowia - zarządzanie bezpieczeństwem informacji w ochronie zdrowia z wykorzystaniem ISO/IEC 27002.

6. PN-ENV 13608-1:2003 - Informatyka w ochronie zdrowia - Bezpieczeństwo przesyłanych danych w opiece zdrowotnej - Część 1: Pojęcia i terminologia.

7. PN-ENV 13608-2:2003 - Informatyka w ochronie zdrowia - Bezpieczeństwo przesyłanych danych w opiece zdrowotnej - Część 2: Bezpieczne obiekty danych.

8. PN-ENV 13608-3:2003 - Informatyka w ochronie zdrowia - Bezpieczeństwo przesyłanych danych w opiece zdrowotnej - Część 3: Bezpieczne kanały przesyłania danych.

9. PN-ISO/IEC 17799:2007 - Technika informatyczna Techniki bezpieczeństwa - Praktyczne zasady zarządzania bezpieczeństwem informacji.
10. PN-ISO/IEC 27001:2007 - Technika informatyczna - Techniki bezpieczeństwa - Systemy zarządzania bezpieczeństwem informacji - Wymagania.

11. Rozporządzenie Ministra Zdrowia z dnia 28 marca 2013 r. w sprawie wymagań dla Systemu Informacji Medycznej, Dz. U. z 2013 r., poz. 463.

12. Ustawa z dnia 28 kwietnia 2011 r. o systemie informacji w ochronie zdrowia, Dz. U. z 2011 r., nr 113, poz. 657 z późn. zm.

13. Ustawa z dnia 18 września 2001 r. O podpisie elektronicznym, tekst jednolity: Dz. U. z 2013 r., poz. 262. 14. Ustawa z dnia 17 lutego 2005 r. o informatyzacji działalności podmiotów realizujących zadania publiczne, Dz. U. z 2005 r., nr 64, poz. 565 z późn. zm.

\section{Література.}

1. Коваленко О. С. Стандартизація інформаційних систем медичного обслуговування з урахуванням загальноєвропейської інтеграції / О. С. Коваленко, В. І. Буряк // Клиническая информатика и телемедицина. - 2004. - № 1. - С. 35-41.

2. Лях Ю. Е. Введение в телемедицину / Ю. Е. Лях, А. В. Владзимирский. - Донецк : Лебедь, 1999. - 101 с. - (Очерки биологической и медицинской информатики).

3. Майоров О. Ю. Інформаційні системи охорони здоров’я (госпітальні інформаційні системи) - дань моді чи необхідність (техніко-економічне обгрунтування упровадження програмного комплексу «С-Госпіталь $® »)$ / О. Ю. Майоров, Л. Б. Білов, С. А. Нєженський // Клінічна інформатика та телемедицина. - 2004. - Т. 1, Вип. 1. - С. 1-12.

4. Мінцер О. П. Інформаційне відображення лікувальнодіагностичного процесу на рівні логіки роботи з даними / О. П. Мінцер, М. Ю. Болгов // Український журнал телемедицини та медичної телематики. - 2007. - Т. 5, № 2. - С. 128-138.

5. Перспективы внедрения телемедицинских технологий для лиц пожилого возраста в Одесском регионе / Л. С. Годлевский, В. В. Дець, К. И. Степаненко [и др.] // Біофізичні стандарти та інформаційні технології в медицині : матер. наук. конф. - Одеса : Астропринт, 2004. - С. 48-52.

6. Пйонтко Н. В. Інформаційна технологія автоматичної сегментації частково спотворених зображень / Н. В. Пйонтко, М. П. Карпінський // Науковий вісник НЛТУ України : зб. наук.-тех. праць. - 2015. - Вип. 25.2. - С. 311-317.

7. Хаімзон I. I. Розробка та дослідження ефективності нових інформаційних технологій ведення, обробки та обліку медичної документації в умовах відділення стаціонару : автореф. дис. на здобуття наук. ступеня д-ра техн. наук : спец. 05.13.02 «Математичне моделювання в наукових дослідженнях» / I. I. Хаімзон ; НАН України, Ін-т кібернетики ім. В. М. Глушкова. - К., 1995. - 30 c. 
8. Юдін О. К. Захист інформації в мережах передачі даних : підручник / О. К. Юдін, О. Г. Корченко, Г. Ф. Конахович. - К. : Вид-во ТОВ «НВП» ІНТЕРСЕРВІС», 2009. - 716 c.

9. Acta Bio-Optica et Informatica Medica Inżynieria Biomedyczna [Electronic resource]. - Retrieved from http:// www.inzynieria-biomedyczna.com.

10. Blim M. Bezpieczeństwo danych w nowoczesnej telemedycynie (część 1) / M. Blim, J. Mikulik // Zabezpieczenia. - 2014. - No. 1. - P. 20-25.

11. Blim M. Bezpieczeństwo danych w nowoczesnej telemedycynie (część 2) / M. Blim, J. Mikulik // Zabezpieczenia. - 2014. - No. 2. - P. 22-29.

12. Instytut Techniki i Aparatury Medycznej [Electronic resource]. - Retrieved from http://www.itam.zabrze.pl.

13. International Classification for Primary Care [Electronic resource] / WONCA. - 1997.

14. International Classification of Diseases. Clinical Modification - Procedures. - Virginia, USA : St. Anthony Publishing Inc, 1991. - 9th Revision.

15. International Classification of Diseases and Health Related Problems / WHO. - Geneva, 1992. - 10th Revision, Vol. I-III.

16. Internationale Klassifikation der Prozeduren in der Medizin / Deutschen Institut für Medizinische Dokumentation und Information. - Berlin, 2000.

17. ISO 9735:1987, baza normatywna EDIFACT.

18. ISO/HL7 21731:2006, Informatyka medyczna. HL7 model referencyjny v.3.

19. Krzyminiewski R. Projekt MONTE [Electronic resource] / R. Krzyminiewski. - Retrieved from http://www. monte.amu.edu.pl.

20. Martsenyuk V. P. Development and application of information system of recording (selfrecording) patients for consultation of university clinics specialists / V. P. Martsenyuk, P. R. Selskyy, A. V. Semenets // Ukrainian journal of telemedicine and medical telematics. - 2013. Vol. 11, No. 2. - P. 173-178.

21. Martsenyuk V. P. Performance of telemedicine technology usage for increasing quality of treatement and diagnostical work of primary care / V. P. Martsenyuk, P. R. Selskyy // Actual problems of pharmaceutical and medical science and practice. - 2013. - Vol. 12, No. 3. - P. 53-54.

22. Materiały inf. NIDRR 2000 USA(Narodowego Instytutu Badań i Rehabilitacji Osób Niepełnosprawnych) na temat ośrodka rehabilitacyjnego Rehabilitation Engineering Research Center (RERC) [Electronic resource]. - Retrieved from za: www.immdhealt.com.

23. Materiały informacyjne konferencji «E-health 2012» / Wrocławski Medyczny Park Naukowo-Technologiczny. Wrocław, 2012.

24. Nałęcz Institute of Biocybernetics and Biomedical Engineering Polish Academy of Sciences [Electronic resource]. - Retrieved from http://www.ibib.waw.pl.

25. Physicians' Current Procedural Terminology (CPTTM) / American Medical Association. - Chicago, 2003. - 4th ed.
26. PN-EN 12251:2005P - Informatyka medyczna Bezpieczna identyfikacja użytkownika w ochronie zdrowia - Zarządzanie i bezpieczeństwo uwierzytelniania z użyciem haseł.

27. PN-EN 14484:2005 - Informatyka medyczna Międzynarodowy przekaz medycznych danych osobowych objętych dyrektywą UE dotyczącą ochrony danych Wysoki poziom polityki bezpieczeństwa.

28. Polskie Towarzystwo TeleMedycyny i e-Zdrowia [Electronic resource]. - Retrieved from http://www. telemedycyna.org.

29. Ustawa z dnia 27 sierpnia 1997 r. o rehabilitacji zawodowej i społecznej oraz zatrudnianiu osób niepełnosprawnych, tekst jednolity: Dz. U. z 2011 r., nr 127, poz. 721 z późn. zm.

\section{References.}

1. Kovalenko, O. S., Buryak, V. I. (2004). Standartizatsiya informatsiinikh sistem medichnogo obslugovuvannya z urakhuvannyam zagal'noievropeis'koi integratsii [Standardization of information systems of health care, taking into account European integration]. Klinicheskaya informatika i telemeditsina (Clinical informatics and telemedicine), 1, 35-41[In Ukrainian].

2. Lyakh, Yu. E., Vladzimirskii, A. V. (1999). Vvedenie $\mathrm{v}$ telemeditsinu [Introduction to telemedicine]. Donetsk: Lebed' [In Russian].

3. Maiorov, O. Yu., Bilov, L. B., Niezhens'kii, S. A. (2004). Informatsiini sistemi okhoroni zdorov'ya (gospital'ni informatsiini sistemi) - dan' modi chi neobkhidnist' (tekhniko-ekonomichne obgruntuvannya uprovadzhennya programnogo kompleksu «C-Gospital'®») [Health information systems (hospital information system) - a tribute to fashion or necessity (feasibility study for the implementation of the program complex «C-Gospital@»]. Klinicheskaya informatika i telemeditsina (Clinical informatics and telemedicine), 1(1), 1-12 [In Ukrainian].

4. Mintser, O. P., Bolgov, M. Yu. (2007). Informatsiine vidobrazhennya likuval'no-diagnostichnogo protsesu na rivni logiki roboti $\mathrm{z}$ danimi [The information display on the logic level of data handling diagnostic and treatment process]. Ukraïns'kii zhurnal telemeditsini ta medichnoi telematiki (Ukrainian journal of telemedicine and medical telematics), 5(2), 128-138 [In Ukrainian].

5. Godlevskii, L. S., Dets', V. V., Stepanenko, K. I., Prybalovets, T, V., Bezhik, N. V., Smirnov, I. V., Bayazitov, N. R. (2004). Perspektivy vnedreniya telemeditsinskikh tekhnologii dlya lits pozhilogo vozrasta $\mathrm{v}$ Odesskom regione [Prospects for the introduction of telemedicine technologies for the elderly in the Odessa region]. In Biofizichni standarti ta informatsiini tekhnologii $\mathrm{v}$ meditsini [Biophysical standards and information technologies in medicine]: materials of scientific conference (pp. 48-52). Odesa: Astroprint [In Russian].

6. Piontko, N. V., Karpins'kii, M. P. (2015). Informatsiina tekhnologiya avtomatichnoi segmentatsii chastkovo 
spotvorenikh zobrazhen' [Information technology of automatic segmentation of partially distorted images]. Naukovii visnik NLTU Ukraini (Scientific bulletin of UNFU): collection of scientific papers, 25.2, 311-317 [In Ukrainian]. 7. Khaimzon, I. I. (1995). Rozrobka ta doslidzhennya efektivnosti novikh informatsiinikh tekhnologii vedennya, obrobki ta obliku medichnoï dokumentatsii v umovakh viddilennya statsionaru [Development and research of the effectiveness of new information technologies of conducting, processing and recording of medical records in the hospital department]: thesis abstract d-r tech. sci. Kyiv. 8. Yudin, O. K., Korchenko, O. G., Konakhovich, G. F. (2009). Zakhist informatsii v merezhakh peredachi danikh [Protection of information in data networks]: the textbook. Kyiv: INTERSERVIS.

9. Acta Bio-Optica et Informatica Medica Inżynieria Biomedyczna. Retrieved from http://www.inzynieriabiomedyczna.com.

10. Blim, M., Mikulik, J. (2014). Bezpieczeństwo danych w nowoczesnej telemedycynie (część 1). Zabezpieczenia, 1, 20-25.

11. Blim, M., Mikulik, J. (2014). Bezpieczeństwo danych w nowoczesnej telemedycynie (część 2). Zabezpieczenia, 2, 22-29.

12. Instytut Techniki i Aparatury Medycznej. Retrieved from http://www.itam.zabrze.pl.

13. International Classification for Primary Care. (1997). WONCA.

14. International Classification of Diseases. (1991). 9th Revision. Clinical Modification - Procedures. Virginia, USA: St. Anthony Publishing Inc.

15. International Classification of Diseases and Health Related Problems. (1992). 10th Revision. WHO, Geneva. 16. Internationale Klassifikation der Prozeduren in der Medizin. (2000). Deutschen Institut für Medizinische Dokumentation und Information. Berlin.

17. ISO 9735:1987, baza normatywna EDIFACT.

18. ISO/HL7 21731:2006, Informatyka medyczna. HL7 model referencyjnyv.3.
19. Krzyminiewski, R. Projekt MONTE. Retrieved from http://www.monte.amu.edu.pl.

20. Martsenyuk, V. P., Selskyy, P. R., Semenets, A. V. (2013). Development and application of information system of recording (selfrecording) patients for consultation of university clinics specialists. Ukrainian journal of telemedicine and medical telematics, 11(2), 173-178.

21. Martsenyuk V. P., Selskyy, P. R. (2013). Performance of telemedicine technology usage for increasing quality of treatement and diagnostical work of primary care. Actual problems of pharmaceutical and medical science and practice, $12(3)$, 53-54.

22. Materiały inf. NIDRR 2000 USA (Narodowego Instytutu Badań i Rehabilitacji Osób Niepełnosprawnych) na temat ośrodka rehabilitacyjnego Rehabilitation Engineering Research Center (RERC). Retrieved from za: www. immdhealt.com.

23. Materiały informacyjne konferencji "E-health 2012”. (2012). Wrocławski Medyczny Park NaukowoTechnologiczny, Wrocław.

24. Nałęcz Institute of Biocybernetics and Biomedical Engineering Polish Academy of Sciences. Retrieved from http://www.ibib.waw.pl

25. Physicians’ Current Procedural Terminology (CPTTM). (2003). American Medical Association. 4th ed. Chicago.

26. PN-EN 12251:2005P - Informatyka medyczna Bezpieczna identyfikacja użytkownika w ochronie zdrowia - Zarządzanie i bezpieczeństwo uwierzytelniania z użyciem haseł.

27. PN-EN 14484:2005 - Informatyka medyczna Międzynarodowy przekaz medycznych danych osobowych objętych dyrektywą UE dotyczącą ochrony danych Wysoki poziom polityki bezpieczeństwa.

28. Polskie Towarzystwo TeleMedycyny i e-Zdrowia. Retrieved from http://www.telemedycyna.org.

29. Ustawa z dnia 27 sierpnia 1997 r. o rehabilitacji zawodowej i społecznej oraz zatrudnianiu osób niepełnosprawnych, tekst jednolity: Dz. U. z 2011 r., nr 127, poz. 721 z późn. zm. 